\title{
Alleviating Environmental Degradation in the Asia-Pacific Region: International cooperation and the role of issue-linkage ${ }^{*}$
}

\author{
Raghbendra Jha, \\ Research School of Pacific and Asian Studies \\ Australian National University
}

\begin{abstract}
This paper argues that the most important environmental challenge within the Asia-Pacific region is that of uninternalised externalities. While developed countries have put in place mechanisms of governance and regulatory structures that internalise most of their domestic environmental external effects the same cannot be said of domestic environmental external effects of developing countries and transnational environmental external effects, although these are some of the most pressing environmental problems facing the countries in the region. Whereas developing countries are paying a high price for uninternalised domestic externalities they and the developed countries have an important stake in finding internalisation solutions to transnational environmental externalities. The paper argues that absence of linkage among these issues and other outcomes of keen interest to developing countries (viz. trade negotiations and the possibility of side payments) has made progress in this area impossible. Hence there is a case for institutional innovation to facilitate Coasian deal-making among these countries through issue linkage.
\end{abstract}

All correspondence to:

Prof. Raghbendra Jha, Australian South Asia Research Centre, Division of Economics, Research School of Pacific and Asian Studies, Australian National University, Canberra, ACT 0200

Phone: + 61261252683

Fax: $\quad+61261250443$

Email: r.jha@anu.edu.au

\footnotetext{
* I am grateful to the John D. and Catherine T. MacArthur Foundation for financially supporting this research.
} 


\section{Introduction}

'People are no longer satisfied only with declarations. They demand firm action and concrete results. They expect that the nations of the world, having identified a problem, will have the vitality to act.' Swedish Prime Minister, Olof Palme, whose country hosted the Stockholm Conference, 1972.

This call to action by Prime Minister Palme at what was the first major international conference to address global environmental problems has, unfortunately, remained substantially unrequited. Global (and Asia-Pacific) negotiations during the time since the Stockholm Conference are yet to result in widely accepted plans for action on redressing environmental degradation. Discussions on such issues have centred on a (elusive) search for principles to guide the global regime (sustainable development and Agenda 21) rather than on the search for operational mechanisms that actually improve environmental quality through incentive based mechanisms. Two key elements characterize the present global environmental regime. The first is a set of international principles (somewhat short of a treaty) embodied in Agenda 21 and the Rio declarations, which emerged from the 1992 Rio summit. These principles reflect an attempt to build a global environmental regime based on declarations, not operational mechanisms. The second is a series of around 180 largely issue-specific environmental treaties (either global or involving subsets of countries) that cover a range of issues and agents including sharing of research, binding commitments on the use of instruments and emission levels, regional as well as global arrangements, property-rights-type agreements, as well as joint reduction agreements as in the Kyoto Protocol. ${ }^{1}$ A small number of more recent treaty arrangements (Montreal and Kyoto Protocols) move in the direction of internalisation.

\footnotetext{
${ }^{1}$ For a description of these treaties see the website http://sedac.ciesin.columbia.edu/entri/index.jsp.
} 
One of the difficulties in articulating a common Asia-Pacific position on the desired environmental regime is the large difference between the environmental concerns facing the various countries of the region. Details are provided in Section II. Jha and Whalley (2001) argue that a broad class of difference lies in the distinction between degraders and pollutants/emissions and their relative importance — particularly in the case of developing countries. Much of the literature has the tendency to equate environmental problems in developing countries with pollutants (or emissions). Much of the extant discussion has been influenced by data availability, including that collected by the Global Environmental Monitoring System (GEMS) supported by UNEP. ${ }^{2}$ This focus on pollutants has meant that in much literature there is less emphasis on what others have called degradation defined as uninternalised externalities seen in soil erosion, congestion, open access resource and similar concerns, where physical emissions are less the problem. Jha and Whalley (2001) argue that to discuss environmental problems in developing countries (or to compare them with those in developed countries) without reference to these problems is incomplete. The effects of these degraders are large and pervasive, and their severity and interaction with economic process often differs sharply from that of pollutants.

The paucity of data about environmental degradation in developing countries means that there are few reliable estimates of the social costs of such degradation. The studies that exist are limited in terms of both methodology and coverage. Even so Jha and Whalley (2001) in reviewing some of this evidence indicate that the costs of such degradation are large - perhaps in excess of $10 \%$ of GDP on an annual basis in some countries. They find that these costs are dominated by degradation rather than pollutant effects (perhaps $3 / 4$ of the total effect). This factor would need to be taken into account in any environmental

\footnotetext{
${ }^{2}$ This includes data on a range of environmental indictors including BOD, airborne SO2 concentrations, heavy metal levels (lead, arsenic, mercury and cadmium), untreated human waste and other air and water quality indicators.
} 
cooperation within the Asia-Pacific region. If the balance of costs is skewed more to degradation than to the effects of pollutants, degradation should perhaps receive more attention. The debate should not get overtaken by greenhouse gases or the Kyoto Protocol and international cooperation should help design environmental policy that helps redress these costs in the developing countries of the region in exchange for support for action on trans-national pollution.

A related point is that the relationship between economic growth, policy reform and environmental quality, and comparisons of the environmental situation either across economies or through time in light of our characterization of the developing country environmental regime. To the extent recent literature focuses on differences in outcomes across countries or over time in terms of levels of various environmental indicators, the issue is whether degradation effects can give a different picture. Jha and Whalley (2001) show that that degradation impacts could well behave differently from pollutants; soil erosion problems, for instance, seem to progressively recede as income per capita rises, since the population in agriculture falls and plot sizes rise; while outward oriented trade policies draw labour into urban areas from rural areas, adding to congestion in urban areas but reducing the pressure on agricultural land. Thus, whereas higher economic growth pursued through greater industrialization could lead to higher emissions, the reduction in population pressure on agriculture would reduce degradation. This has implications for the validity of the environmental Kuznets curve (EKC) $)^{3}$. While authors contributing to these literatures are clear in labelling their EKC analyses to be primarily of pollutant levels, users of this research naturally tend to think of the results as giving guidance on the wider environmental situation in the countries discussed. Without explicit reference to degradation effects, the picture can be incomplete. This has no doubt influenced the perception of the EKC as indicating that

\footnotetext{
${ }^{3}$ For a review see Panayotou (2003) and recent literature on trade and environment by Copeland and Taylor (1994), Antweiler, Copeland and Taylor (1998), and Coxhead and Jayasuriya (2003).
} 
further economic growth in developing countries would lead to increases in emissions whereas further growth in developed countries would only help alleviate emissions and, therefore, influence the perceived terms of cooperation between developed and developing countries in environmental management. However, as Jha and Murthy (2003) demonstrate that once the set of pollutants is expanded to include degradation the shape of the EKC undergoes considerable change and it is no longer possible to argue that continued economic growth by the developing countries would hurt the environment whereas continued economic growth in developed countries would alleviate environmental degradation. Hence, the terms of cooperation should go beyond conceiving of disaster environmental scenarios associated with the anticipated sustained rapid economic growth of the major economies in the region including China and India.

Clearly the impetus for international cooperation would come from assessments of potential gain. From the point of view of the developing countries of the region welfare gains from moving to full internalisation would seem to be the more appropriate comparative measure of severity of environmental problems across countries (or changes through time). If the costs are as high as those reported in Jha and Whalley (2001) then it would follow that internalisation gains relative to GDP are significant for developing countries (and probably larger than for developed countries) raising the issue of why a higher degree of internalisation has not occurred. With an appropriate evaluation of benefits, developing countries would place high value on such internalisation and would place high value on mechanisms that would help them attain it. A first pre-requisite for successful international cooperation in the area of the environment in Asia-Pacific is an emphasis on internalisation mechanism for environmental externalities within developing countries.

This paper emphasizes the basis for environmental cooperation in the Asia-Pacific region and identifies issue-linkage as an important characteristic of this process. Progress on 
international or trans-boundary environmental problems — in which at present the developed countries of the region have the most stake at present — would be facilitated by linkage with progress on issues in which developing countries have a more immediate stake. Local degradation effects have already been mentioned. It is argued in this paper that welfare effects can be enhanced by expanding the list of potential issues for linkage with international environmental negotiation. The plan of this paper is as follows. Section II briefly overviews the state of the environment in the Asia-Pacific region emphasizing, in particular, the importance of the distinction between emissions and degradation. Section III assesses human vulnerability to extant environmental conditions in the Asia-Pacific. Section IV emphasizes the importance of designing mechanisms for internalising external effects - both within countries and transnationally - and assessing the impediments to such internalisation. Section V advances some suggestions for furthering such internalisation and section VI concludes. 


\section{The State of the Environment in the Asia-Pacific Region}

This section briefly overviews the state of the environment in the Asia-Pacific region. The UNEP's views on key environmental issues confronting the Asia-Pacific region are summarized in Table 1. Table 2 details the geographical distribution of environmental issues and their proximate causes for South Asia, Southeast Asia, South Pacific region and Northeast Asia.

Table 1: Key Environmental Issues Confronting the Asia-Pacific

\begin{tabular}{|c|c|}
\hline Land & $\begin{array}{ll}\text { - } & \text { Land Degradation } \\
\text { - } & \text { Desertification } \\
\text { - } & \text { Land Use Change }\end{array}$ \\
\hline Forests & $\begin{array}{ll}\text { - } & \text { Forest Degradation } \\
\text { - } & \text { Deforestation }\end{array}$ \\
\hline Biodiversity & $\begin{array}{ll}\text { - } & \text { Habitat loss } \\
\text { - } & \text { Forest loss and Degradation } \\
\text { - } & \text { Alien Species }\end{array}$ \\
\hline Freshwater & $\begin{array}{l}\text { - Water Scarcity } \\
\text { - } \quad \text { Pollution }\end{array}$ \\
\hline Coastal and Marine & $\begin{array}{l}\text { - Degradation of coastal and marine resources } \\
\text { - } \quad \text { Pollution due to mining and coastal development }\end{array}$ \\
\hline Atmosphere & $\begin{array}{ll}\text { - } & \text { Air quality } \\
\text { - } & \text { Ozone depletion } \\
\text { - } & \text { Greenhouse gas emissions and climate change }\end{array}$ \\
\hline Urban areas & $\begin{array}{ll}\text { - } & \text { Air Pollution } \\
\text { - } & \text { Waste management } \\
\text { - Water supply and sanitation }\end{array}$ \\
\hline Disasters & $\begin{array}{ll}\text { - } & \text { Floods } \\
\text { - } & \text { Droughts } \\
\text { - } & \text { Volcanoes } \\
\text { - } & \text { Earthquakes }\end{array}$ \\
\hline
\end{tabular}

Source: Global Environmental Outlook, 2003, London and Sterling, VA, US: UNEP 
Table 2.a Key Environmental Issues and Causes in South Asia

\begin{tabular}{|c|c|c|}
\hline Country & Key Issues & Key Causes \\
\hline Afghanistan & $\begin{array}{l}\text { Soil degradation; overgrazing; deforestation } \\
\text { desertification; loss of biodiversity; food security risks; } \\
\text { natural disasters such as earthquakes and droughts. }\end{array}$ & $\begin{array}{l}\text { Population growth; increased demand for bio-fuels, } \\
\text { building materials, and agricultural lands }\end{array}$ \\
\hline Bangladesh & $\begin{array}{l}\text { Marginalized populations forced to live on and cultivate } \\
\text { primacy; reliance flood-prone land; loss of biodiversity; } \\
\text { limited access to deficits in urban potable water; } \\
\text { water-borne diseases prevent; water } 30 \text { largest pollution, } \\
\text { especially of fishing areas; arsenic pollution } \\
\text { marine-based of drinking water; urban au pollution; soil } \\
\text { degradation; and run-off; deforestation; severe } \\
\text { overpopulation: natural disasters on industrial (especially } \\
\text { floods and cyclones which kill thousands of of people } \\
\text { and causes heavy economic losses every year); food } \\
\text { security risks; industrial pollution; import of } \\
\text { hazardous waste. }\end{array}$ & $\begin{array}{l}\text { High population density and urban on private } \\
\text { transport; urbanization and infrastructure (including } \\
\text { one of the world's } \\
\text { cities Dhaka); increases in unmanaged tourism; green } \\
\text { revolution/agrochemicals high demand for bio-fuels; } \\
\text { lack of controls effluent; over exploitation and/or } \\
\text { pollution groundwater. }\end{array}$ \\
\hline Bhutan & Soil erosion; limited access to potable water & High rates of urbanization. \\
\hline India & $\begin{array}{l}\text { Deforestation; soil erosion; overgrazing; desertification } \\
\text { loss of biodiversity; au pollution; water pollution; huge } 30 \\
\text { largest population base and large growth rate is } \\
\text { overstraining industrial effluents natural resources; } \\
\text { natural disasters such as floods, marine- cyclones and } \\
\text { landslides are common; high death rates and ailments } \\
\text { associated with indoor au pollution. }\end{array}$ & $\begin{array}{l}\text { High rates of urbanization and deficits in urban } \\
\text { infrastructure (including in four of world's cities); } \\
\text { reliance on private transport and vehicle emissions; } \\
\text { increases in based tourism; green revolution/ } \\
\text { agrochemicals and run-off; reliance on bio-fuels. }\end{array}$ \\
\hline Iran & $\begin{array}{l}\text { Air pollution, especially in urban areas; deforestation; } \\
\text { overgrazing; desertiflcation; oil pollution in the Persian } \\
\text { Gulf; inadequate supplies of potable water; food security } \\
\text { risky natural disasters such as floods, earthquakes, and } \\
\text { landslides are common. }\end{array}$ & $\begin{array}{l}\text { Excessive pressure on forests and rangelands; high } \\
\text { rates of urbanization and deficits in urban } \\
\text { infrastructure (including one of world's } 30 \text { largest cities } \\
\text { - Tehran); inefficient public and private transport; } \\
\text { vehicle emissions, refinery operations, and industrial } \\
\text { effluents. }\end{array}$ \\
\hline Maldives & $\begin{array}{l}\text { Climate change; beach erosion; depletion of freshwater } \\
\text { aquifers; degradation of marine habitats. }\end{array}$ & $\begin{array}{l}\text { High population densities; increases in } \\
\text { marine-based tourism; sea level rise. }\end{array}$ \\
\hline Nepal & $\begin{array}{l}\text { Deforestation; soil erosion and degradation; loss of } \\
\text { transport; biodiversity; water pollution; natural disasters } \\
\text { such as floods and landslides in rural areas; food } \\
\text { security risks. }\end{array}$ & $\begin{array}{l}\text { High rates of urbanization; reliance on private } \\
\text { increased demands for timber; increased population } \\
\text { density and cultivation of marginal lands. }\end{array}$ \\
\hline Pakistan & $\begin{array}{l}\text { Water pollution; seasonal limitations on the availability of } \\
\text { natural freshwater resources; majority of the population } \\
\text { lacks access to potable water; deforestation soil erosion; } \\
\text { coastal habitat loss and degradation of marine } \\
\text { environment; desertiflcation; loss of biodiversity: natural } \\
\text { disasters, mainly due to floods. }\end{array}$ & $\begin{array}{l}\text { High rates of urbanization and deficits in urban } \\
\text { infrastructure; industrial wastes; population } \\
\text { increases in coastal areas and rise in tourism; } \\
\text { depletion of mangroves for aquaculture; over fishing; } \\
\text { increased demands for timber/bio-fuels; } \\
\text { hunting/poaching; green revolution/ agrochemicaLs } \\
\text { and runoff. }\end{array}$ \\
\hline Sri Lanka & $\begin{array}{l}\text { Deforestation; soil erosion; pollution by municipal and } \\
\text { domestic waste; loss of biodiversity; coastal degradation; } \\
\text { limited access to potable water; water-borne diseases } \\
\text { prevalent. }\end{array}$ & $\begin{array}{l}\text { Excessive pressure on forests; increases in } \\
\text { marine-based tourism; poaching; sea level rise; } \\
\text { deficits in urban infrastructure; water pollution by } \\
\text { municipal and industrial waste, and agricultural } \\
\text { run-off; extensive mining activit }\end{array}$ \\
\hline
\end{tabular}

Source: UNESCAP and ADB (2000) 
Table 2.b Key Environmental Issues and Causes in Southeast Asia

\begin{tabular}{|c|c|c|}
\hline Country & Key Issue & Key Causes \\
\hline Brunei Danussalam & Seasonal Smoke and Haze & $\begin{array}{l}\text { Transboundary pollution from forest fires in neighbouring } \\
\text { countries }\end{array}$ \\
\hline Cambodia & $\begin{array}{l}\text { Soil erosion; sedimentation; water pollution, } \\
\text { deforestation; loss of biodiversity -threat to natural } \\
\text { fisheries }\end{array}$ & $\begin{array}{l}\text { Unmanaged waste and effluent discharge into Tonlesap } \\
\text { lake; destruction of mangrove swamplands }\end{array}$ \\
\hline Indonesia & $\begin{array}{l}\text { Deforestation; loss of biodiversity; water pollution; } \\
\text { air pollution in urban areas; national and } \\
\text { transboundary seasonal smoke and haze; land } \\
\text { degradation; pollution of Malacca strait }\end{array}$ & $\begin{array}{l}\text { Deficiencies in urban infrastructure - unmanaged } \\
\text { industrial wastes and municipal effluents and waste; } \\
\text { vehicular congestion and emissions; extensive land } \\
\text { clearance and forest fires for pulp wood and of palm } \\
\text { production; extensive and unmanaged mining activities; } \\
\text { national and transboundary industrial pollution (from } \\
\text { Singapore and Malaysia), tourist developments in coastal } \\
\text { regions beyond exerting carrying capacity. }\end{array}$ \\
\hline Lao PDR & $\begin{array}{l}\text { Deforestation; loss of biodiver;ity; soil erosion; } \\
\text { limited access to potable water; water-borne } \\
\text { diseases prevalent. }\end{array}$ & $\begin{array}{l}\text { Land clearance; shifting cultivation; inadequate water } \\
\text { supply and sanitation infrastructure. }\end{array}$ \\
\hline Malaysia & $\begin{array}{l}\text { Urban air pollution; water pollution; deforestation; } \\
\text { loss of biodiversity; loss of mangrove habitats; } \\
\text { national and transboundary smoke/haze. }\end{array}$ & $\begin{array}{l}\text { Vehicular congestion and emission; deficiencies in urban } \\
\text { infrastructure - industrial and municipal effluents; } \\
\text { extensive land clearance and forest fires for pulp wood } \\
\text { and oil palm production; unmanaged coastal } \\
\text { developments; tourist developments in coastal regions } \\
\text { beyond existing carrying capacity }\end{array}$ \\
\hline Myanmar & $\begin{array}{l}\text { Deforestation; loss of biodiversity urban air } \\
\text { pollution; soil erosion; water contamination and } \\
\text { water-bome diseases prevalent. }\end{array}$ & $\begin{array}{l}\text { Land clearance; excessive mineral extraction; vehicular } \\
\text { congestion and emissions, deficiencies in urban } \\
\text { infrastructure - unmanaged industrial and municipal } \\
\text { effluents. }\end{array}$ \\
\hline Philippines & $\begin{array}{l}\text { Deforestation in watershed areas; loss of } \\
\text { biodiversity; soil erosion; air and water pollution in } \\
\text { Manila leading to waterborne disease; pollution of } \\
\text { coastal mangrove habitats; natural disasters such } \\
\text { as earthquakes and floods. }\end{array}$ & $\begin{array}{l}\text { Illegal forest cutting; land clearance; rapid urbanization } \\
\text { and deficiencies in urban infrastructure - unmanaged } \\
\text { industrial and municipal effluents, inadequate water } \\
\text { supply and sanitation; tourist developments in coastal } \\
\text { regions beyond existing carrying capacity; }\end{array}$ \\
\hline Singapore & $\begin{array}{l}\text { Industrial pollution; limited natural fresh water } \\
\text { resources; waste disposal problems. }\end{array}$ & $\begin{array}{l}\text { Seasonal smoke/haze; limited land availability for waste } \\
\text { disposal }\end{array}$ \\
\hline Thailand & $\begin{array}{l}\text { Deforestation; loss of biodiversity; land degradation } \\
\text { and soil erosion; shortage of water resources in dry } \\
\text { season and flooding in rainy season; conflict of } \\
\text { water users; coastal degradation and loss of } \\
\text { mangrove habitat; urban air pollution; pollution from } \\
\text { solid waste, hazardous materials and hazardous } \\
\text { waste. }\end{array}$ & $\begin{array}{l}\text { Non-strategic and sporadic development and destruction } \\
\text { of critical watersheds; unmanaged aquaculture } \\
\text { developments; growth in tourist industries exceeding } \\
\text { growth in tourism carrying capacity, deficiencies in urban } \\
\text { and rural infrastructure, particularly central draining - } \\
\text { freshwater resources being polluted by domestic and } \\
\text { industrial wastes and sewage runoff. }\end{array}$ \\
\hline Viet Nam & $\begin{array}{l}\text { Deforestation and soil degradation; loss of } \\
\text { biodiversity; loss of mangrove habitat; water } \\
\text { pollution and threats to marine life; groundwater } \\
\text { contamination; limited potable water supply; natural } \\
\text { disasters such as floods. }\end{array}$ & $\begin{array}{l}\text { Land clearance for industrial zones; extensive } \\
\text { aquaculture and overfishing; growing urbanization and } \\
\text { infrastructure deficiencies - inadequate water supply and } \\
\text { sanitation, particularly in major cities of Hanoi and Ho Chi } \\
\text { Minh }\end{array}$ \\
\hline
\end{tabular}


Table 2.c Key Environmental Issues and Causes in the South Pacific Region

\begin{tabular}{|c|c|c|}
\hline Country & Key Issue & Key Cause \\
\hline $\begin{array}{l}\text { Australia and New } \\
\text { Zealand }\end{array}$ & $\begin{array}{l}\text { Soil erosion; soil salinity; degradation of in-land } \\
\text { and marine waters; depletion of wetlands; } \\
\text { desertification; depletion of fisheries; loss of } \\
\text { biodiversity. }\end{array}$ & $\begin{array}{l}\text { Overgrazing; poor farming practices; land clearance and } \\
\text { deforestation; invasion of exotic species; overfishing; } \\
\text { over development of the coastal zone; shipping pollution }\end{array}$ \\
\hline $\begin{array}{l}\text { Melanesian Countries } \\
\text { (Papau New Guinea, } \\
\text { Solomon Islands, New } \\
\text { Caledonia, Vanuatu, and } \\
\text { Fiji) }\end{array}$ & $\begin{array}{l}\text { Deforestation; land degradation/soil erosion; loss } \\
\text { of biodiversity; water degradation and limited } \\
\text { access to potable water; local depletion of } \\
\text { coastal fisheries. }\end{array}$ & $\begin{array}{l}\text { Commercial logging; land clearance; mining; climate } \\
\text { change; population growth and deficiencies in urban and } \\
\text { rural infrastructure; over fishing. }\end{array}$ \\
\hline $\begin{array}{l}\text { Mid-sized open islands of } \\
\text { Polynesia and Micronesia } \\
\text { (Tonga, Samoa, } \\
\text { American Samoa, French } \\
\text { Polynesia, Palau, Guam, } \\
\text { and the Northern Mariana } \\
\text { Islands) }\end{array}$ & $\begin{array}{l}\text { Deforestation; soil erosion; loss of biodiversity; } \\
\text { local depletion of coastal fisheries; degradation } \\
\text { of in-land and marine waters. }\end{array}$ & $\begin{array}{l}\text { Expansion of commercial agriculture and agro pollution } \\
\text { of run-off; population growth and expansion into marginal } \\
\text { lands; indiscriminate collection of coral and shells; } \\
\text { invasion of exotic species; overfishing; hunting, } \\
\text { particularly of native sea turtles. }\end{array}$ \\
\hline $\begin{array}{l}\text { Small island micro-states } \\
\text { (Cook Islands, Kiribati, } \\
\text { Tuvalu, Federated States } \\
\text { of Micronesia, Marshall } \\
\text { Islands, Niue, and Nauru }\end{array}$ & $\begin{array}{l}\text { Vulnerability to natural disasters; water } \\
\text { degradation and limited access to potable water; } \\
\text { coastal erosion. }\end{array}$ & $\begin{array}{l}\text { Climate change; groundwater salinization deficiencies in } \\
\text { urban and rural infrastructure }\end{array}$ \\
\hline
\end{tabular}

Source: UNESCAP and ADB (2000) 
Table 2.d Key Environmental Issues and Causes in Northeast Asia

\begin{tabular}{|c|c|c|}
\hline Country & Key Issue & Key Cause \\
\hline PR China & $\begin{array}{l}\text { Acidification of inland waterways and acid deposition; } \\
\text { degradation of water supply; loss of agricultural land; } \\
\text { loss of biodiversity; vulnerability to natural disaster, } \\
\text { especially drought and flooding. }\end{array}$ & $\begin{array}{l}\text { Over reliance on low-grade } \\
\text { coal; inadequate } \\
\text { infrastructure for the } \\
\text { management of municipal } \\
\text { effluent; deforestation and } \\
\text { soil erosion; poverty. }\end{array}$ \\
\hline Japan & $\begin{array}{l}\text { Excess volumes of industrial and municipal waste; } \\
\text { pollution from dioxins, endocine disrupters and other } \\
\text { industrial hazards; increasing greenhouse gas } \\
\text { emissions; vehicle emissions; loss of biological } \\
\text { diversity. }\end{array}$ & $\begin{array}{l}\text { Unsustainable consumption } \\
\text { patterns; lack of emission } \\
\text { control in waste incineration } \\
\text { and industrial processes } \\
\text { (nationaland } \\
\text { transboundary);increasing } \\
\text { vehicle ownership; habitat } \\
\text { destruction due to } \\
\text { development projects and } \\
\text { invasion of alien species. }\end{array}$ \\
\hline $\begin{array}{l}\text { Russian } \\
\text { Federation }\end{array}$ & $\begin{array}{l}\text { Air pollution in hot spots and major cities; pollution of } \\
\text { inland and marine waters; deforestation; loss of } \\
\text { biodiversity; soil erosion and contamination; } \\
\text { radioactivity. }\end{array}$ & $\begin{array}{l}\text { Inefficient heavy industry and } \\
\text { reliance on coal for power } \\
\text { generation; deficiencies in } \\
\text { urban infrastructure } \\
\text {-unmanaged industrial } \\
\text { wastes and municipal } \\
\text { effluents and waste; urban } \\
\text { congestion and inefficient } \\
\text { vehicles; unsustainable } \\
\text { agricultural practices, and } \\
\text { excessive chemical } \\
\text { application; historical sites of } \\
\text { nuclear weapons testing. }\end{array}$ \\
\hline Rep. of Korea & $\begin{array}{l}\text { Limited access to potable water; urban air pollution; } \\
\text { environmental contamination; aridification of inland } \\
\text { waterways and arid deposition. }\end{array}$ & $\begin{array}{l}\text { High levels of uncontrolled } \\
\text { atmospheric releases from } \\
\text { industry; release of dioxins; } \\
\text { endocrine disrupters, and } \\
\text { other industrial hazards; } \\
\text { transboundary air pollution } \\
\text { tom neighbouring countries. }\end{array}$ \\
\hline North Korea & $\begin{array}{l}\text { Localized air pollution; water pollution and limited } \\
\text { access to potable supplies; vulnerability to natural } \\
\text { disaster, especially drought and flooding. }\end{array}$ & $\begin{array}{l}\text { High levels of uncontrolled } \\
\text { atmospheric releases tom } \\
\text { industry; deficiencies in } \\
\text { urban infrastructure } \\
\text {-industrial and municipal } \\
\text { effluents; poverty }\end{array}$ \\
\hline Mongolia & $\begin{array}{l}\text { Localized air pollution; soil erosion and desertification; } \\
\text { loss of biodiversity; water pollution and limited access } \\
\text { to potable supplies. }\end{array}$ & $\begin{array}{l}\text { Overgrazing; deforestation; } \\
\text { reliance on low-grade coal; } \\
\text { promotion of rapid } \\
\text { urbanization }\end{array}$ \\
\hline
\end{tabular}

Source: Complied from WRI 1996 
Table 3 distils the information in Table 2 for Asian developing countries and restructures it to underscore the need to make the distinction between degradation and emission/pollution in their context.

\section{Table 3: A Pollutant/Degradation Classification Scheme for Environmental Externalities in} Asian Developing Countries

\section{Pollutants}

Toxic contaminants -

Organo-chlorines, dioxins, pesticides, grease and oil, acid and caustic metals; mainly discharges from mines, chemical producers, pulp and paper plants, and leather tanning factories

Untreated fluid waste - $\quad$ Untreated sewage discharges into rivers, streams, open ditches - water borne disease

Domestic solid waste - $\quad$ Poorly managed solid waste spreads infectious disease, blocks urban drainage channels, with risk of flooding and water borne disease

Smoke and burning -

Health related effects (respiratory damage, heart and lung disease, cancer) from burning dung, wood, and crop residues; vehicle exhaust; coal burning; smoke

\section{Degradation}

Soil erosion -

Sedimentary transfer of topsoil to neighboring plots, river estuaries, hydro dams - silting, accompanied by leaching of soil

Soil quality - $\quad$ Pesticide residues impact on production of neighboring plots

Open access resources - $\quad$ over exploitation of resources due to ill defined property rights - firewood/forests; fisheries; shared aquifers and water tables

Congestion/traffic - $\quad$ time loss and elevated accident risk from poorly regulated traffic; lowered air quality in urban areas

Source: Jha and Whalley (2001).

I comment briefly on specific environmental problems in the Asia-Pacific region.

\section{Land Degradation}

Land degradation problems of particular concern in Asia and the Pacific include erosion, compaction, acidification, declining soil and organic matter, weed infestation, soil fertility depletion and biological degradation. Oldeman (1994) estimates that about 13\% (or 85 million ha) of the land in Asia and the Pacific is degraded. Most of this is in Asia but it is estimated that 104 million ha were degraded in the Pacific sub-region where large-scale 
clearance of forestland has caused a decline in soil structure and fertility and where invasive species are the predominant land cover on many islands. The most severe water erosion occurs in the Himalayas, Central Asia, China, the South Pacific and Australia and wind erosion affects Afghanistan, India, Iran and Pakistan most severely.

Chemical soil degradation is mainly caused by agricultural mismanagement. In parts of northern India and Bangladesh, soils have acidified and salinized, and have been losing nutrients. Large tracts of land in Cambodia, Malaysia, Thailand and Vietnam have been degraded by acid sulphates. Poor soil nutrient balances (between phosphorus, nitrogen and potassium) are common in Australia, Bangladesh, Nepal, Pakistan and Sri Lanka.

Saline soils cover 60 million ha of agricultural land in the region and Australia in particular is facing severe land salinization problems. Excessive extraction from groundwater and surface water resources, and rising water tables brought about by faulty irrigation systems, have increased the occurrence of surface water and soil salinity. Serious soil contamination affects the northern part of the region, Australia and New Zealand. The contaminants include cadmium (contained in fertilizer), hexavalent chromium, lead, arsenic, trichloroethylene, tetrachloroethylene and dioxine concentrates. Health issues from these contaminants are common. The major soil polluters in the region are now the chemical and electroplating industries in Japan and South Korea. Heavy metals are also present in agricultural land (as a result of fertilizer application) and near mines and refineries (due to chemical discharges). Soil contamination from lead and arsenic contamination is prevalent throughout South and Southeast Asia. Irrigation with untreated effluent has also caused contamination and soil acidifaction in many areas; in Mongolia, for instance, waste disposal and wastewater discharges are the principal causes of soil contamination (UNDP 2000). 
In addition, the stress on soil for cultivation is quite severe in South and South-east Asia.Another major factor contributing toward land degradation in the Asia-Pacific region is the extent of land utilization. The state of land utilization in 2000 is given in Table 4.

Table 4: Land Utilization (percentage of total land area): Asia and the Pacific

\begin{tabular}{|l|c|c|c|}
\hline Region & Area under crops & Areae under pasture & Total \\
\hline Australia and New Zealand & 6.5 & 52.7 & 59.2 \\
\hline Central Asia & 10.0 & 63.2 & 73.2 \\
\hline $\begin{array}{l}\text { Northwest Pacific and East } \\
\text { Asia }\end{array}$ & 12.7 & 45.1 & 57.8 \\
\hline South Asia & 36.3 & 14.5 & 50.8 \\
\hline Southeast Asia & 20.5 & 3.9 & 24.4 \\
\hline South Pacific & 2.6 & 1.1 & 3.7 \\
\hline
\end{tabular}

Source: Global Environmental Outlook, 2003, London and Sterling, VA, US: UNEP

The densely populated region of South Asia uses more than one-third of its total land for cultivation. Reasons for land problems include underpricing of resources and subsidization of agricultural inputs such as fertilizers have played a part in maintaining pressure on land. A major policy failure leading to land degradation is insecure land tenure although in some cases fragmentation of holdings has increased to such an extent that there is over-exploitation of land holdings.

A related problem is that of desertification. Of the 1977 million ha of drylands in Asia more than half are affected by desertification (UNCCD 1998).

\section{Forests}

Land degradation problems are directly related to land-use practices, particularly agricultural expansion and intensification. In Thailand, for example, forest cover has declined from 56\% to $24 \%$ of total area between 1965 and 1997. In Japan arable land has been converted to residential use. 
Asia and the Pacific region accounts for $18.8 \%$ of the global forests. Within the region, Northwest Pacific and East Asia has the largest forest area (29.3\%) followed by Southeast Asia (29.1\%), Australia and New Zealand (22.3\%), South Asia (11.7\%), South Pacific (4.8\%) and Central Asia (2.7\%). Changes in forest areas between 1990 and 2000 are noted in Table 5.

Table 5: Change in forested land $1990-2000$ by sub-region: Asia and the Pacific

\begin{tabular}{|l|c|c|c|c|c|c|}
\hline & $\begin{array}{c}\text { Total land area } \\
\text { (million ha) }\end{array}$ & $\begin{array}{c}\text { Total forest 1990 } \\
\text { (million ha) }\end{array}$ & $\begin{array}{c}\text { Total forest 2000 } \\
\text { (million ha) }\end{array}$ & $\begin{array}{c}\text { \% of land } \\
\text { forested in 2000 }\end{array}$ & $\begin{array}{c}\text { Change 1990- } \\
\text { 2000 (million ha) }\end{array}$ & $\begin{array}{c}\text { \% change } \\
\text { per year }\end{array}$ \\
\hline $\begin{array}{l}\text { Australia and } \\
\text { New Zealand }\end{array}$ & 795.0 & 164.9 & 162.5 & 20.4 & -2.4 & -0.1 \\
\hline Central Asia & 391.6 & 16.6 & 19.3 & 4.9 & 2.7 & 1.6 \\
\hline $\begin{array}{l}\text { Northwest Pacific } \\
\text { and East Asia }\end{array}$ & 1147.8 & 195.2 & 212.7 & 18.5 & -1.4 & -1.0 \\
\hline South Asia & 640.3 & 86.3 & 85.3 & 13.3 & -23.3 & -1.0 \\
\hline Southeast Asia & 434.5 & 234.7 & 211.4 & 48.7 & -1.2 & -0.4 \\
\hline South Pacific & 53.9 & 36.4 & 35.1 & 65.2 & -7.7 & -0.1 \\
\hline $\begin{array}{l}\text { Total Asia and the } \\
\text { Pacific }\end{array}$ & 3463.2 & 734.0 & 726.3 & 21.0 & & -1.0 \\
\hline
\end{tabular}

Source: Global Environmental Outlook, 2003, London and Sterling, VA, US: UNEP

Deforestation and degradation are critical issues threatening biodiversity, ecosystem stability and the long-term availability of forest products as well as depleting the natural resource base underpinning many national economies (UNESCAP and ADB 2000). Population pressure, heavy dependence on fuelwood, timber and other products, as well as the conversion of forests to agricultural, urban and industrial land are the underlying factors for deforestation in the region. Lack of properly defined property rights have led to overgrazing, and shifting cultivation. In addition, as forests have become degraded, so fire, pests, disease and natural disasters have caused greater damage. 
More than 40\% (and the highest diversity) of the world's mangroves grow along the coasts of South and Southeast Asia. A further 10\% grow in the Pacific. More than $60 \%$ (some 11 million ha) of Asia's mangroves have already been converted to aquaculture and more have been cleared to make way for rice farming or urban and industrial land use. Those that remain are exploited for timber, fuelwood, tannin and food items (UNESCAP and ADB 2000). The depletion of forests for fuelwood is common in South Asia. Fires are a major cause in Southeast Asia as is commercial logging. In the Pacific islands commercial logging is also a problem.

Species diversity in the region is extremely high. Indonesia is thought to support more species, with more endemic species than any other country in the world, closely followed by several others including Australia and China. Deforestation is adding to loss of biodiversity. Major river systems are drying, groundwater is increasingly overexploited and pollution is a major concern (Fuggle and Smith 2000); as a result biodiversity impacts are likely to be substantial. Analysis of the World Commission on Dams (WCD 2000) has shown that the environmental, hydrological and economic arguments used to support dam construction are often flawed. Table 6 presents an overview of the threat to biodiversity in the Asia-Pacific region and Table 7 of the extent of protection given to biodiversity locations.

Table 6: Number of Threatened Vertebrates: Asia and the Pacific

\begin{tabular}{|l|c|c|c|c|c|}
\hline & Mammals & Birds & Reptiles & Amphibians & Fishes \\
\hline Critically Endangereda $^{\text {a }}$ & 68 & 60 & 13 & 15 & 48 \\
\hline Endangeredb $^{\mathrm{b}}$ & 167 & 95 & 27 & 22 & 46 \\
\hline Vulnerablec $^{c}$ & 291 & 368 & 66 & 30 & 153 \\
\hline
\end{tabular}

Notes: a: critically endangered is defined as extremely high risk of extinction in immediate future

$\mathrm{b}$ : endangered is defined as very high risk of extinction in immediate future

c. vulnerable is defined as high risk of extinction in medium term.

Does not include marine species recorded by ocean area.

Source: Global Environmental Outlook, 2003, London and Sterling, VA, US: UNEP 
Table 7: Protected Areas

\begin{tabular}{|l|l|l|l|}
\hline Australia and New Zealand & 108.42 million ha & $13.64 \%$ & 3231 sites \\
\hline $\begin{array}{l}\text { Northwest Pacific and East } \\
\text { Asia }\end{array}$ & 89.78 million ha & $7.79 \%$ & 1041 sites \\
\hline Southeast Asia & 48.69 million ha & $11.20 \%$ & 1506 sites \\
\hline South Asia & 28.41 million ha & $4.44 \%$ & 675 sites \\
\hline Central Asia & 10.45 million ha & $2.69 \%$ & 195 sites \\
\hline South Pacific & 1.25 million ha & $2.31 \%$ & 141 sites \\
\hline
\end{tabular}

Source: Global Environmental Outlook, 2003, London and Sterling, VA, US: UNEP

\section{Freshwater}

The Asia-Pacific region accounts for about 36\% of the global run-off. Even so, water scarcity and pollution are key issues and the region has the lowest per capita availability of freshwater: renewable water resources amounted to about $3690 \mathrm{~m}^{3}$ per capita/year in mid1999 for the 30 largest countries in the region (WRI 2000). In absolute terms, China, India and Indonesia have the largest water resources, more than one-half of the region's total. However several countries including Bangladesh, India, Pakistan and Korea already suffer from water scarcity or water stress. More will do so as populations and consumption increase. Agriculture is the biggest consumer (86\%), with smaller amounts going to industry (8\%) and domestic use (6\%) (UNDP 2000).

Over the years, water pollution has emerged as a major issue. Pollutants include pathogens, organic matter, nutrients, heavy metals and toxic chemicals, sediments and suspended solids, silt and salts. South Asia — particularly India — and Southeast Asia are facing severe water pollution problems. Rivers such as the Yellow River (China), the Ganga (India) and Amu and Syr Darya (Central Asia) top the list of the world's most polluted rivers (World Commission on Water 1999). In cities in the developing countries of the region, most 
water bodies are now heavily polluted with domestic sewage, industrial effluents, chemicals and solid waste.

Water pollution has affected human health. In the Pacific Islands, especially in some atoll communities, use of polluted groundwater for drinking and cooking has led to health problems such as diarrhoea, hepatitis, and occasional breaks of typhoid and cholera. Groundwater in districts of West Bengal, India, and in some villages of Bangladesh, for example, is contaminated with arsenic at levels as much as 70 times higher than the national drinking water standard of $0.05 \mathrm{mg} /$ litre. According to one report "With the majority of the country's 68000 villages potentially at risk, UN scientists estimate that the arsenic may soon be killing 20000 Bangladeshis a year.” (Pierce 2001)

Inadequate water supply and poor sanitation cause more than 500,000 infant deaths a year as well as a huge burden of illness and disability in the region (UNEP 1999). Some 89\% of the total Disability Adjusted Life Years (DALYs) are due to diseases related to inadequate water supply and poor sanitation in India and other countries (World Bank 2000). Cholera is prevalent in many countries, particularly those where sanitation facilities are poor such as Afghanistan, China and India (WHO 2000).

Of the global population without access to improved sanitation or water supply, most live in Asia (WHO and UNICEF 2000). In South-west Pacific water supply and sanitation appear to be quite good with 93\% of the population having access to improved sanitation and 88\% to improved water supply. However, these figures are probably biased upwards because of the inclusion of Australia and New Zealand. Only an estimated 48\% of the Asian population has sanitation coverage (WHO and UNICEF 2000) — less than in any other region of the world. The situation is worse in rural areas, where only $31 \%$ of the population have improved sanitation, compared to $79 \%$ for the urban areas. 


\section{Coastal and Marine Area Pollution}

In the past 30 years, depletion of coastal resources such as fisheries, mangroves and coral reefs has emerged as a critical issue in Asia and the Pacific. Urbanization, industrialization and tourism are the major reasons for this. It is estimated that more than $60 \%$ of Asia's mangroves have already been converted to aquaculture farms (UNESCAP and ADB 2000). Besides encroaching on mangroves, aquaculture has led to the release of nutrients, pathogens and potentially hazardous chemicals into marine waters. In India, prawn farms have been constructed in low-lying coastal areas, depriving farmers of agricultural land, causing salinization of groundwater in coastal villages and polluting waterways with excess nutrients. Over-exploitation of fish stocks and poor aquaculture practices are of concern $n$ Bangladesh (UNEP 2001), India (ADB 2000), Pakistan, Sri Lanka, many Pacific Island countries and some other countries.

Coral reefs are under stress in many areas, especially those near shallow shelves and dense populations. More than half the world's coral reefs are located in the Pacific Island countries, and large areas are already degraded. The causes range from global, large-scale changes in the ocean environment and global warming, to tourism and recreation, high population density and economic development in coastal areas in the past 15 years. Most coral reefs in South Asia were adversely affected by coral bleaching in mid-1998. Increasing water temperatures and increased levels of dissolved carbon dioxide in seawater have resulted in the widespread death of stony corals throughout the tropics (Wilkinson 2000).

Pollution has considerably degraded the coastal and marine environment, including estuaries of the region, over the past 30 years. Increased wastes from land-based urban, industrial and agricultural activities as well as from offshore oil and gas exploitation are discharged untreated in the coastal region. The most significant sources of pollution include oil from ships, sewage and other domestic waste, and industrial effluents. The shipping of oil 
coupled with increased emphasis on offshore oil exploration makes the northern Indian Ocean vulnerable to oil pollution. The enhanced use of agrochemicals on land and discharge of chemicals into seawater is a common problem. An estimated 1800 tonnes of pesticides enter the Bay of Bengal every year (Holmgrem 1994). The Sea of Japan has high untreated, or partially treated sewage, operational leaks, discharge of hydrocarbons and waste dumping, and the Soviet Union dumped nuclear waste for decades. Tourism is another contributory factor. Sediment load in the coastal zone of South Asia is high, mainly as a result of soil erosion caused by poor land-use practices and construction activities. Annually about 1.6 billion tonnes of sediment reach the Indian Ocean from rivers flowing through the Indian subcontinent. Coastal erosion is severe in many areas including the Andaman Coast, the Gulf of Thailand, Japan and the Pacific Islands.

\section{Atmosphere}

Air pollution levels in the most populated cities in Asia are among the highest in the world, producing serious human health impacts and affecting aquatic and terrestrial ecosystems. Transport is often a very significant contributor. The other sources include industrial emissions, burning of solid and liquid fuels for power generation, and burning of biomass and other fuels such as charcoal for household use. Although the number of cars per capita is relatively low in the Asian developing countries the total size of the motorized fleet has been growing sharply. During 1975-92 the number of motorized vehicles in Sri Lanka doubled whereas in India the number of cars has been doubling every seven years for the past 30 years (ADB 2000). Indoor air pollution is often a more severe health hazard than outdoor air pollution. Most rural inhabitants in the region use twigs, grass, dried animal dung, crop residues, wood charcoal and kerosene as household fuels. Coupled with inadequate ventilation this results in highly contaminated indoor air. Health effects include acute respiratory infection in children chronic obstructive lung disease, adverse pregnancy 
outcomes and lung cancer in women. Acute respiratory diseases are prevalent in the rural and/or hilly areas of Afghanistan, Bangladesh, Bhutan, India, Nepal, Pakistan and Sri Lanka where indoor air pollution is high.

Two particular forms of air pollution - the Asian (atmospheric) brown cloud and the ozone layer are briefly discussed below.

\section{The Asian Brown Cloud}

In Spring 1999 scientists working on the project Indian Ocean Experiment (INDOEX) discovered a dense brownish pollution haze layer covering most of South and Southeast Asia and the tropical region of the Indian Ocean. The researchers tracked the haze over an area of about 10 million $\mathrm{km}^{2}$, and believe it forms over much of the Asian continent. The haze is a mixture of pollutants, mainly soot, sulphates, nitrates, organic particles, fly ash and mineral dust, formed by fossil fuel consumption and rural biomass burning. It reduces the sunlight reaching the tropical Indian Ocean by as much as $10 \%$, with a larger reduction over the Indian subcontinent. Simulations with global climate models indicate that the haze could have major impacts on the monsoon circulation, regional rainfall patterns and vertical temperature profile of the atmosphere. (UNEP 2001). UNEP (2001) and Nakicenovic and Swart (2000) document that the anthropogenic aerosols released during the atmospheric brown cloud are projected to become the dominant component of anthropogenic aerosols worldwide in the next 25 years.

Haze problems are also prevalent in the region due to forest fires in Southeast Asia. The most serious episode occurred in 1997, when the effects of forest fires in Indonesia extended to neighbouring countries including Brunei Darussalam, Papua New Guinea, Philippines, Singapore and Thailand. 


\section{Ozone Depletion}

Data from Australia and New Zealand show that ultraviolet levels there appear to be rising by about $10 \%$ per decade. India and China are the largest regional producers and users of CFCs. The Multilateral Fund of the Montreal Protocol and GEF have been helping the region meet the goals of the Montreal Protocol.

Per capita use of commercial energy increased annually by $1.9 \%$ in South Asia and 3\% in East Asia and the Pacific during 1980-98 (World Bank 2001). $\mathrm{CO}_{2}$ is the main anthropogenic greenhouse gas. Methane emissions are also high in South Asia, accounting for almost $50 \%$ of the global anthropogenic emission of $\mathrm{CH}_{4}$. Areas under most threat from climate change include marine ecosystems, coastal systems, human settlements and infrastructure (IPCC 1998). Countries in the Northwest Pacific and east Asia sub-regions and the Pacific Island countries may be particularly vulnerable to phenomenon such as sea level rise because many of their human settlements and industrial facilities are located in coastal or low-lying areas.

\section{$\underline{\text { Urban Areas }}$}

Air pollution is common — particularly in developing country cities. In countries such as India, Indonesia, Nepal, Malaysia and Thailand vehicles with two-stroke engines, such as motorcycles and three-wheel taxis, comprise more than half of all motor traffic and pollute heavily. Poor maintenance of vehicles, poor fuel quality and poor road conditions also contribute. The burning of biomass such as firewood and agricultural wastes is a further source of air pollution in many poor areas.

In Australia and New Zealand there is a high dependence on private motor vehicles which leads not only to the need to clear land for roads but also to increasing emissions of carbon dioxide, lead, zinc and copper. 
Much of the solid waste generated in urban centres remains uncollected and is either deposited in surface waters and empty lots, or burned in streets. This problem has worsened considerably in the past 30 years.

Serious health and environmental problems can be caused by poor waste disposal. In the Pacific Islands freshwater is scarce, and solid waste disposal methods that contaminate water are frequently a source of intestinal diseases and ear and eye infection. In India an outbreak of the bubonic plague in1994 was the result of inadequate solid waste disposal.

For most cities, providing an adequate and safe supply of water for domestic and industrial uses is a major problem. The sewage system in many major cities still cannot support a high-density urban environment with the result that sewage is often discharged directly to drains or waterways, or disposed of in individual septic tanks that are poorly maintained.

Sanitation services are less developed than water supply with $23 \%$ of urban residents still lacking adequate sanitation. This is for a sample of 38 Asia-Pacific countries for the year 2000. Another major urban environmental problem is flooding and land subsidence.

Bangkok, Mumbai and Calcutta are all prone to flooding in the monsoon season.

\section{Disasters}

About 75\% of the world's major natural catastrophes between 1970 and 1997 occurred in the Asia and Pacific region, mostly in poverty-ridden developing countries (UNESCAP and ADB 2000).

The highest number of deaths occurred in South Asia (the sub-region with the highest population density and the lowest per capita income) and the lowest number in Australia and New Zealand (the sub-region with the lowest population density and the highest per capita income). 
Table 8: Asia-Pacific Disasters in 1972-2000

\begin{tabular}{|l|c|c|c|}
\hline & $\begin{array}{c}\text { Number killed } \\
\text { (thousands) }\end{array}$ & $\begin{array}{c}\text { Number affected } \\
\text { (thousands) }\end{array}$ & $\begin{array}{c}\text { Damage } \\
\text { (US \$1000) }\end{array}$ \\
\hline South Asia & 761 & $2,164,034$ & 60,881 \\
\hline Southeast Asia & 73 & 284,074 & 33,570 \\
\hline Northwest Pacific and East Asia & 606 & $1,447,643$ & 986 \\
\hline Central Asia & 3 & 4,895 & 21,900 \\
\hline Australia and New Zealand & 1 & 15,761 & 3,139 \\
\hline South Pacific & 4 & 4,061 & 437,649 \\
\hline Total & 1,447 & $3,920,467$ & \\
\hline
\end{tabular}

N.B. : $\quad$ Central Asia figures relate to $1992-93$ to 2000.

Source: Global Environmental Outlook, 2003, London and Sterling, VA, US: UNEP

Environmental degradation and change are becoming increasingly important in relation to both the occurrence and impact of natural disasters. Deforestation, for example, is now frequently linked to severe flood events and landslides. Overexploitation of water resources has already resulted in sub-regional environmental disasters such as the drying up of the Aral Sea in Central Asia. Most of the countries in the Northwest Pacific and East Asia sub-region and the Pacific Island countries will be particularly vulnerable to climate change and associated sea-level rise because so much human settlements and so much industrial infrastructure are located in coastal or lowland areas.

Rapid population growth, urbanization and weak land-use planning are some of the reasons why poor people move to fragile and high risk areas which are more exposed to natural disasters. Moreover, the rapid growth of industries in urban areas has induced ruralurban migration. 


\section{Human Vulnerability to Environmental Problems}

The extant literature has emphasized increasing human vulnerability to environmental problems. McMichael (2001) documents the increasing dependence of human health on the environment. According to WHO (1997):

(i) Deteriorating environmental conditions are a major contributory factor to poor health and poor quality of life. Mismanagement of natural resources, excessive waste productions and associated environmental conditions that affect health, pose major challenges to sustainable development;

(ii) Impoverished populations living in rural and peri-urban areas are at greatest risk from degraded environmental conditions. The cumulative effects of inadequate and hazardous shelter, overcrowding, lack of water supply and sanitation, unsafe food, air and water pollution and high accident rates as well as greater susceptibility to disasters, have serious effects on the health of these vulnerable groups. Poor environmental quality is directly responsible for some $25 \%$ of all preventable ill health, with diarrhoeal diseases and acute respiratory infections heading the list;

(iii) Two-thirds of all preventable ill health due to environmental conditions occurs among children;

(iv) Air pollution is a major contributor to a number of diseases, and to a lowering of the quality of life in general.

Overall it is estimated that $25-33 \%$ of the global burden of disease is attributable to environmental factors (Smith, Corvalan and Kjellstrom (1999)). Murray and Lopez (1996) estimate that environment-related premature death and illness account for $18 \%$ of the total burden of diseases in the developing world. This comprises contributions from water supply and sanitation (7\%), indoor air pollution (4\%), vector-borne diseases (3\%), urban air pollution (2\%) and agro-industrial waste (1\%). WHO (2002) estimates that every year 
environmental hazards kill three million children under the age of five. Of these $40-60 \%$ are due to acute respiratory infection resulting from environmental factors. Microbiological contamination of the sea by sewage pollution has precipitated a health crisis of massive proportions globally. Bathing in polluted seas is estimated to cause some 250 million cases of gastroenteritis and upper respiratory disease every year, with an estimated annual cost worldwide of about US\$1.6 billion. Some of these people could be disabled over the longerterm, suggesting that the global impacts of marine pollution are comparable to those of diphtheria and leprosy.

Some authors have argued that food security is also affected by environmental factors. Agricultural growth as a consequence of the Green Revolution has also had an adverse impact on the environment in terms of nutrient mining, increases in soil salinity, waterlogging, depletion of underground water and the release of nitrogen into watercourses.

Human well-being is inextricably linked to ecosystems through the goods and services that the ecosystems provide. These include both marketed goods and services, such as food or forest products, and non-marketed ones such as water flow regulation. Suchak (2002) puts the cost of environmental damage to India in 1992 at US\$ billion a year or 4.5\% of GDP. A breakdown of the estimated costs shows that urban air pollution costs India US\$1.3 billion a year, and water degradation has associated health costs of US\$5.7 billion a year. Land degradation causes productivity losses of around US\$2.4 billion and deforestation leads to annual losses of US\$241 million. In Japan the damage to agricultural crops caused by tropospheric ozone amounts to an estimated US\$166.5 million alone yearly in the Kanto region alone. The potential economic losses of non-marketed ecosystems goods and services and the impact on human vulnerability are likely to be even higher than for marketed goods and services. Equally, little attention is paid to the high economic cost of more gradual environmental degradation and loss of natural resource potential. 
As argued above there is little systematic data on the costs of such degradation and estimates, where they exist, employ varying and mutually non-consistent methodologies.

Even so Table 9 summarizes evidence of the economic costs of such degraders/pollutants and Table 10 reports on time lose due to tariff congestion in select Asian cities.

\section{Table9: $\quad$ Some Estimates of Environmental Costs in Selected Asian Countries}

China

* Productivity losses due to soil erosion, deforestation and land degradation, water shortages and destruction of wetlands in 1990 put at US\$ 13.9-26.6 billion annually or 3.8-7.3\% of GDP

* Health and productivity losses from pollution in cities in 1990 put at US\$ 6.3-9.3 billion, or 1.7-2.5\% of GDP

India

* Total environmental costs of US\$ 13.8 billion in 1992, or 6\% of GDP; urban air pollution costs \$1.3 billion; health costs from water quality at $\$ 5.7$ billion; soil erosion costs at $\$ 2.4$ billion; deforestation costs put at $\$ 214$ million. Traffic related costs, pollution costs from toxic wastes, biodiversity losses excluded.

$\underline{\text { Indonesia }}$

* Health costs of particulate and lead levels above WHO standards in Jakarta put at US\$2.2 billion in 1989, or 2.0\% of GDP

$\underline{\text { Pakistan }}$

* Health impacts of air and water pollution and productivity losses from deforestation and soil erosion put at US\$1.7 billion in the Philippines early 1990's; or 3.3\% of GDP

* Health and productivity losses from air and water pollution in the Manila area put at US\$ 0.3-0.4 billion in the early 1990's, or $0.8-1.0 \%$ of GDP

Thailand

* Health effects of particulate and lead levels in excess of WHO standards put at US\$ 1.6 billion, or 2\% of GDP

Source: Agarwal (1996), ADB (1997), and UN (1998) 
Table 10: Estimates of time losses due to traffic congestion in Asian cities, 1994

\begin{tabular}{|l|c|c|}
\hline City & $\begin{array}{c}\text { Annual cost of time delays } \\
\text { (US\$ millions) }\end{array}$ & $\begin{array}{c}\text { Cost as\% of local } \\
\text { (city-wide) product }\end{array}$ \\
\hline Bangkok & 272 & 2.1 \\
\hline Kuala Lumpur & 68 & 1.8 \\
\hline Singapore & 305 & 0.9 \\
\hline Jakarta & 68 & 0.7 \\
\hline Manila & 51 & 0.6 \\
\hline Hong Kong & 293 & 0.4 \\
\hline Seoul & 154 & 0.9 \\
\hline
\end{tabular}

Source: WRI (1996) and UN (1998)

These and other reports such as those by Jha and Whalley (2001) indicate a continuing and unrelenting human assault on the environmental and natural resource systems that sustain all life on the planet. As daunting as current conditions are, they pale into insignificance when compared with ultimate results of further exploitation of the environment. Thus Angel and Rock (2000) writes that "Most of Asia is in the midst, not at the end, of an urban-industrial led development transition unparalleled in its scale and intensity.” Urban population in Asia has been doubling in size every 15-20 years and will increase by another $69 \%$ by 2025 . Roughly $80 \%$ of the industry that will be operating in 2020 (primarily in urban areas) has yet to be built. If trends continue, by 2010 Asia will produce more sulphur dioxide than Europe and the US combined and by 2020 the Asia region will become the world's largest source of greenhouse gases (Douglass and Ling, 2000). Hence existing trends are unmistakingly pointing in the direction of a fundamentally unsustainable environmental future in the Business-as-usual case (UNEP 2003). 


\section{Barriers to Internalisation: Locally and Globally}

The discussion so far has emphasized that incomplete internalisation — at the local, transboundary and international levels — is perhaps the single most important contributor to environmental problems in the Asia-Pacific region. In view of the high costs associated with such lack of internalisation it is pertinent to inquire into the reasons why such internalisation is not forthcoming.

A complex set of (familiar) reasons is behind the lack of progress toward internal industrialization in the developing countries of the region. These include weak and illdefined property rights over resources, inefficient enforcement (Prasad (2004)), large transactions costs, poor technology of surveillance and poor governance. However, the experience of the developing countries in this regard is not very different from those of developed countries. Developing countries have often been thought of following the development experience of the developed countries with a compressed lag. OECD countries have grown over some 200 years and transformed from primary agricultural to primarily high-technology service providers. Developing countries are following this experience at varying speeds, and in different ways, but the transition time is clearly shorter. Korea, for instance, may have transformed itself from a country with lower income per capita than India in the mid 1950s to a lower income OECD country in 40 years. However, whereas the OECD countries during their years of rapid industrialization could follow a policy of "grow now and clean up later”, the developing countries of today are under considerable strain to clean up. These pressures come from donor governments, international organizations and developed country NGOs and sometimes carry the threat of punitive action. At the height of OECD country industrial revolutions, effectively no environmental controls were in place.

Thus developing countries in the region are subject to the twin pressures of having to raise per capita incomes rapidly and yet clean up during the process. What should be their 
response? Following developed country experience would seem to indicate adopting few environmental controls, and that with income growth environmental quality will improve. Indeed, a great fear is that attempts to heighten environmental regulation will only serve to slow growth, and hence slow eventual achievement of higher environmental quality through growth. On the other hand, with problems of compliance one can argue that perhaps developing countries have no choice but to follow the older developed country industrial revolution experience of largely benign neglect.

There are key differences in the developing country experience in this area compared to the industrial revolution of old. First, the time periods involved are compacted, and hence the flow environmental damage per year during industrialization is larger. Second, the shocks which hit the economies are also much more severe than was true of the old industrial revolutionizers. These latter economies simply did not experience population growth rates of $3 \%$ per year plus massive growth in urban vehicle densities, and other elements contributing to today's environmental ills in the developing world. Not only is the process more compact, the severity of damage time adjusted probably exceeds that experienced in the OECD one hundred years ago. Third, even though weakly administered, there are abatement technologies, which can and are being employed, and even though there is political opposition, environmental management is taking root.

The process of internalisation of environmental external effects has gone much further in developed OECD economies. For instance, in the OECD countries we observe a strong decoupling of emissions of local air pollutants from economic growth. OECD countries have also achieved a strong decoupling between energy use and economic growth over the past 20 years, with the economy growing by $17 \%$ between 1980 and 1998 and energy use falling by the about the same percentage. Water and resource use continued to grow but at a rate slower than GDP growth reflecting a weak decoupling of the two. Thus decoupling of emissions in 
OECD and generally the developed countries has been accomplished through a combination of technological change and a strong environmental policy. The latter consisting of "greening” of fiscal policy, removing subsidies to environmentally harmful activities and the use of economic instruments to internalise environmental cost. For example, a number of EU policy initiatives, such as the Broad Economic Policy Guidelines 2001, among others have promoted a gradual but steady and credible change in the level and structure of the tax rates until external costs are fully reflected in prices, to cope with most of the fundamental structural problem in all developed countries, the unsustainable patterns of production and consumption. In the energy markets these guidelines aim to uses taxes and other marketbased instruments to rebalance prices in favour of reusable energy sources and technologies. Other EU initiatives in this direction are the European Climate Change Programme (ECCP), the directive establishing an EU framework for emissions trading, and the Integrated Product Policy (IPP) all of which aim at realigning price relations and stimulating investments in new technologies that promote sustainable development. Member states are encouraged to improve market functioning by addressing market failures such as externalities through “increased use of market-based systems in pursuit of environmental objectives as they provide flexibility to industry to reduce pollution in a cost effective way, as well as encourage technological innovations”. Economic instruments such as gradual but steady and credible change in the level and structure of tax rates until external costs are fully reflected in prices are promoted as the most efficient means of decoupling economic growth from pollution, as they alter price relations and thereby also drive changes in technology and consumer behaviour (preference) that lie behind the growth-environmental relationship. As exemplified by the energy and transport sectors, the EU decoupling policy consists of demand management through full cost pricing and development of more environmentally friendly alternatives by promoting technological innovations. The United Nations Economic 
Commission for Europe has repeatedly called upon its members to raise the prices of various energy sources to their full economic costs and adapt economic instruments to internalise the costs to human health and the environment associated with energy production and consumption. The aim is to decouple emissions from energy use and energy use from economic growth.

Commensurate progress in these areas in the case of developing or transition countries has been lacking, although some progress has been achieved. Thus since 1990 all economies in transition have made efforts to restructure their energy and transport sectors along market principles and to raise energy prices closer to economic and international levels. However because of the political sensitivity of energy pricing and the lagging reforms in many transition economies a gap of $20-85 \%$ continues to persist between energy prices in economies in transition. For example electricity prices for households in Eastern Europe are only 50 percent of those of the European Union; for industrial consumers, electricity prices are closer to their economic and international levels being 20\% lower than those of the EU. Subsidies on electricity for agriculture continue to be extremely high in India (Jha and Thapa, 2003).

Although gains from internalisation (at the international level) are jointly shared and are substantial, why are custodians of assets not able to agree to manage and conserve assets in return for payment by those who benefit from such practices? From the viewpoint of the developing countries, given the large cost estimates for their country environmental problems, it is likely that these countries will continue to pursue a much more activist environmental policy. However, given the greater cost of local degradation issues, such efforts will have a dominant focus on degradation over pollution. International external effects are more likely to be emphasized in any international environmental cooperation. To 
make such cooperation more attractive to the developing countries of the region, concessions would have to be made to developing countries to enable them to address their domestic environmental concerns - in particular environmental degradation. In fact an enlightened international environmental policy would link the issue of support for domestic internalisation policies in developing countries to cooperation in international environmental agreements such as those on greenhouse gases.

There are several other reasons for this observed lack of internalization at the international level. First, it is difficult for negotiations between groups who have an interest in the management practices used for environmental resources to be put together. For instance, governments may agree to conserve forests but may find it difficult to pursue this if encroachments into forests are done primarily by the poor. Similarly in OECD countries there may be a willingness to pay for environmental protection in poorer countries, but any attempt to estimate this (by survey methods, for instance) will be subject to free riding. The benefits from environmental protection abroad are a public good which is hard to finance through voluntary action. A related problem is that individual countries can free ride on the environmental quality improvement by other countries. Hence some countries may hang back from multilateral negotiation in which they need to pay a price to achieve environmental quality improvements that others will benefit from. This has been emphasized by Barrett (1994). Environmental enforcement also has an important time-inconsistency dimension. OECD countries may strike deals with countries to meet environmental targets such as forest cover, or species populations over a number of years. But if payment for these concessions takes place immediately, more money could potentially be repeatedly requested for environmental compliance. On the other hand if payment is postponed until the end of the agreement, countries that conserve environmental assets have no assurance of getting paid. 
This lack of internalisation denotes an institutional failure. In fact the international institutional architecture reflected in the present global environmental regime, and some 35 years in evolution, does not take as its starting point the design of mechanisms that seek to achieve internalisation of environmental externalities across countries. There is no agency that attempts to achieve Coase's internalising deals across countries that recognizes the many problems in deal making to improve environmental quality. The modern economics literature shows why private negotiation cannot easily complete the deals needed for international environmental internalisation, why intermediary agencies are needed, why scientific standard driven arrangements produce only low level environmental outcomes. In short, why a new global or at least regional (at the Asia-Pacific level) agency for the environment is needed.

Progress in these areas has been scanty and faltering. International environmental negotiations in the region are still in their infancy. In fact the present global economic institutions still reflect their 1940s origins, and focus primarily on trade and finance as the dominant economic linkages between countries, rather than physical linkages.

The central global environmental problem is the relative lack of internalisation of cross border and global externalities. We need an institutional form that seeks to achieve internalisation internationally, and that does this by facilitating Coasian deals based on the perceived interests of the participants. At least since Coase (1960) it is known that bargaining between the parties to an externality would serve to achieve internalisation — no Pigou type tax was needed. Coase argued that the issue of who should pay the additional costs of internalisation was a matter of property rights — who has the rights to what? Bargaining between the parties to an externality would serve to internalise it with payments of compensation for damage to those having the legal rights to pursue redress, and payment to induce reduction of damage by those parties having no such rights. Economic analysis is silent on the issue of who should have such rights. Also in the presence of an externality, 
bargaining (or Coasian deals) may already have been entered into and imposition of taxes or other measures could actually worsen the allocation of resources. Coase's discussion was largely centred upon narrowly defined externalities. In the case of global externalities the number of people affected is in the millions and the transactions costs of such bargaining (which Coase approximated to zero) are likely to large. In fact we have seen some of the reasons why such bargaining may be hard to put in place. However, there is need for an international mechanism to facilitate such bargaining on this large scale. Other ancillary functions that need to be addressed are allowing for verification of completion of contracts and acting as a financial guarantor. While the WTO is cast within a bargaining framework, it is restricted since no cash is involved an the rules of the WTO Charter (via GATT 1994) constrain bargaining (such as the MFN rule). 


\section{Institutional mechanism to facilitate environmental cooperation in the Asia-Pacific Region?}

The principal argument of this paper is that there is an urgent need to develop institutional mechanisms to facilitate deal-making to achieve internalisation of environmental externalities at the transnational level. Experience to date indicates that this is not possible unless the bargaining set is enlarged to ensure that there are adequate gains for all participants. Thus there is a need for issue linkage in the area of environmental negotiation. Jha et al. (2002) indicate some areas where such issue linkage is possible and, indeed, could be welfare improving for Asian developing countries. The issues with which international environmental negotiations could be linked include aid to developing countries to underpin their domestic internalisation efforts, trade concessions by developed countries and cash transfers.

How large is the potential gain from issue linkage in the area of environmental negotiation? This issue requires much more careful analysis than it has been afforded so far. Seminal work on this was done by Perroni, Whalley and Wigle (1999). They construct a simulation model to compute the gains from trade negotiations as the opportunity set is enlarged. They point out that since the early 1990s the link between trade and environment has been an important issue of contention between developed and developing countries. Developed countries have argued that trade restrictions are needed on certain types of trade in order to safeguard the environment whereas developing countries have viewed this as a new type of restriction on their exports and have, hence, opposed these measures. Instead, they seek financial incentives for adopting growth-reducing environmental measures. Perroni, Whalley and Wigle argue that (1999) argue that this is not the only policy option available. For one, there may be trade-environment linkages in international negotiations. Another alternative is issue linkage across trade and environment with side payments. These policy alternatives are compared in a two-region numerical simulation model. The two regions are the North and the South. The North is represented by the OECD countries and the South by 
28 key developing countries with substantial environment assets. Six countries from the Asia-Pacific region belong to this "South” group. These are India, Indonesia, Malaysia, Myanmar and Papua New Guinea. The model is benchmarked to 1990 and projected over a 100-year time horizon. Alternative North-South negotiation scenarios are modelled. A trade war would favour the North and would cause considerable economic damage to the South. If trade negotiations were not linked with environmental concessions both North and South benefit with the South eliminating all tariffs whereas the North would get to keep some of them. If joint trade and environment negotiations take place the North would completely eliminate its tariffs, whereas Southern environmental management improves significantly. Some trade barriers would remain in the South as a concession by the North for better environmental management. Thus this exchange generates gains for both the North and the South but it is not sufficient to eliminate tariffs in the South. This can be attained if the set of negotiation instruments is expanded to include side (cash) payments. The "right" amount of cash transfer would lead to elimination of tariffs by the South and maximise potential global welfare gains. Thus there are significant gains associated with enlarging the scope for negotiations to link the twin issues of trade and environment and enlarge the set of instruments to include cash transfers.

Hence there appears to be some evidence of substantial gains from issue linkage in the area of environmental negotiation. Perhaps there is room for an initiative in this direction within the Asia-Pacific region.

What is the institutional preparedness of the countries within the region to put into effect such issue linkage? Two environmental camps presently exist in the West. One component has been opposed to trade liberalization as it associates this with environmental decay. Wallach (1999) is a statement of this position. A second component argues that trade liberalization and economic growth should succeed only if it fully accounts for environmental 
conditions. This position has some powerful supporters including the UN Secretary General, Kofi Annan. Both environmental camps draw their strength from strong public support for environmental quality. As Peritore (1999) indicates, public polls in both developed as well as developing countries indicate a populace increasingly frustrated with the inability and/or unwillingness of governments to halt environmental deterioration.

In the Western countries public support and the mobilization of NGOs is step-by-step creating a system of corporate legitimisation transcending boundaries, and beyond statecentric regulation of commerce (either domestic or international). It is contingent upon commercial organization meeting universal standards of acceptable practice (Newell 2000). The corporation's compliance with social and environmental norms is viewed as being just as important as its compliance with legal requirements.

There is some evidence that leading multinational companies recognize the changing nature of legitimacy as evident in their policies to maintain uniformly high environmental standards in their facilities regardless of the countries in which these facilities are located. ISO standards are being increasingly adopted by firms all over the world (Chang-Xing, 1999 and Jha, Markandy, and Vossenaar, 1999). Many Western European countries are leading efforts to identify and require new product standards, especially in relation to the environment.

These efforts are slowly becoming recognized and accepted in the US as well. However, there is little evidence that developing countries are picking up on the changes. Their aversion to linking trade and environment in the extant manner is well-known. A common reason given for this linkage is the fear of losing a comparative advantage in the export market. The fear is based on a twofold concern: First, many Asian countries are suspicious of protectionist interests in the West masquerading as environmentalists or human 
rights advocates. ${ }^{4}$ Further Asian societies decry the double standards that are being applied to them, forcing them to adopt environmental standards much stricter that those that applied to Western countries in their economic development process. These are well-founded concerns — however, given the urgency of the environmental situation, a way forwards needs to be found.

Asian States have frequently resorted to the principle of State sovereignty to justify their defensive posture toward an environment-trade linkage. ASAEN, for example, has argued forcefully for the right of developing countries to permanent sovereignty over their natural resources, and have rejected the view that the world is a global common, to be dealt with collectively. It can be argued, however, that the claim of State sovereignty can be a transparent mask for pursuing self-interest by existing regimes. Herein lies an important difference between OECD and the developing countries of Asia. Whereas the thrust for environmental action is increasingly concentrated in the hands of non-governmental agencies in the case of developed countries and this gets reflected in their approach to regional organizations as institutions, some Asian States view these organizations as institutions to enhance State capabilities, not transcend them. Morrison et al. (1997, 34) wrote: "the central purpose has been to consolidate the stability, security, and prosperity of the present states and state system, not to subsume sovereignty in larger entities.” This State-centric approach becomes even more pronounced when dealing with forces outside the region. Thus there is a conflict in their negotiating position with the developed countries where there has been an emphasis on reducing internal state sovereignty.

To enable the developing countries in the region to transcend such entrenched positions, gains from issue linkage should be demonstrated. Deal-making to obtain environmental concessions from the developing countries in return for assistance in

\footnotetext{
${ }^{4}$ On this point see Verbruggen et al (1998).
} 
internalising local environmental externalities; trade concessions and side payments could be pursued. A possible institutional mechanism in support of such issue linkage is a regional (Asia-Pacific) environmental organisation along the lines of the World Environmental Organisation discussed in Jha et al. (2002), Lodefalk and Whalley (2002), and Whalley and Zissimos (2000, 2001, 2002). 


\section{Conclusions}

This paper has argued that the most important environmental challenge within the AsiaPacific region is that of uninternalised externalities. While developed countries have put in place mechanisms of governance and regulatory structures that internalise most of their domestic environmental external effects the same cannot be said of domestic environmental external effects of developing countries and transnational environmental external effects, although these are some of the most pressing environmental problems facing the countries in the region. Whereas developing countries are paying a high price for uninternalised domestic externalities they and the developed countries have an important stake in finding internalisation solutions to transnational environmental externalities. The paper argues that absence of linkage among these issues and other outcomes of keen interest to developing countries (viz. trade negotiations and the possibility of side payments) has made progress in this area impossible. Hence there is a case for institutional innovation to facilitate Coasian deal making among these countries through issue linkage. 


\section{References}

ADB (Asian Development Bank) (1997) Emerging Asia-Changes and Challenges, Manila.

ADB (2000) Asian Development Outlook, New York: Oxford University Press.

ADB (2001) Asian Environment Outlook 2001, Manila: Asian Development Bank.

Agarwal, A. (1996) 'Pay-offs to Progress', Down to Earth (Centre for Science and Environment, New Delhi) 5(10): 31-9.

Angel, D. and M. Rock (2000) (eds) Asia's Clean Revolution: Industry, Growth and the Environment, Sheffield, UK: Greenleaf Publishing.

Antweiler, W., B.R. Copeland, and M.S. Taylor (1998) 'Is Free Trade Good for the Environment?' National Bureau of Economic Research Working Paper No. 6707, August.

Barrett, S. (1994) 'Self-enforcing international environmental arrangements', Oxford Economic Papers, 46(4): 878-94.

Bendell, J. (ed.) (2000) Terms of Endearment: Business, NGOs and Sustainable Development, Sheffield, UK: Greenleaf Publishing.

Chang-Xing, D. (1999) 'ISO-14001: The Severe Challenge for China', in W. Wehrmeyer and Y. Mulugetta (eds), Growing Pains, Sheffield, UK: Greenleaf Publishing.

Coase, R. (1960) ‘The Problem of Social Cost’, Journal of Law and Economics, .

Copeland, B.R. and M.S. Taylor (1994) 'North-South Trade and the Environment' Quarterly Journal of Economics, 109: 755-87.

Coxhead, I. and S. Jayasuriya (2003) The Open Economy and the Environment, Cheltenham, UK: Edward Elgar.

Douglass, M. and O. Ling (2000) 'Industrializing Cities and the Environment in Pacific Asia: Toward a Policy Framework and Agenda for Action', in Asia' Clean Revolution

Fuggle, R. and W. Smith (2000) 'Large Dams in Water and Energy Resource Development in the Peoples’ Republic of China' Cape Town: World Commission on Dams. Accessed at: http://www.dams.org/studies/cn/cn_exec.htm

Hayes, P. and L. Zarsky (1994) 'Environmental Issues and Regimes in Northeast Asia', International Environmental Affairs, 6(4):

Holmgren, S. (1994) An Environmental Assessment of the Bay of Bengal Region. BOPG/REP/67. Madras, Bay of Bengal Program.

IPCC (1998) The Regional Impacts of Climate Change: An Assessment of Vulnerability, International Panel on Climate Change, Geneva.

Jha, R. and K. Murthy (2003) ‘An Inverse Global Environmental Kuznets Curve’, Journal of Comparative Economics, 31(2): 352-68. 
Jha, R., M. Panda and A. Ranade (2002) 'An Asian Perspective on a World Environmental Organization’, World Economy, 25(5), 643-57.

Jha, R. and C. Schatan (2001) 'Debt for Nature: A Swap Whose Time has Gone?’ United Nations: ECLAC, Estudios Y Perspectivas 4, 2001, Mexico City.

Jha, R. and P. Thapa (2003) 'Infrastructure and Electricity Sector Reforms in India', in Indian Economic Reforms, London: Palgrave-Macmillan, pp. 334-54.

Jha, R. and J. Whalley (2001) 'The Environmental Regime in Developing Countries', in C. Carraro and G. Metcalf (eds) Behavioural and Distributional Effects of Environmental Policy, Chicago: University of Chicago Press for NBER, pp. 217-49.

Jha, V., Markandya, A. and R. Vossenaar (1999) Reconciling Trade and the Environment: Lessons from Case Studies in Developing Countries, Northampton, MA: Edward Elgar.

Lodefalk, Magnus; Whalley, J. (2002) "Reviewing Proposals for a World Environmental Organization, World Economy, 25(5): 601-17.

McMichael, A. (2001) Human Frontiers, Environments and Disease: Past Patterns, Uncertain Futures, Cambridge: Cambridge University Press.

Morrison, C., A. Kujima and H. Maull (1997) Community Building in the Pacific Asia, New York: The Trilateral Commission.

Murray, C. and A. Lopez (1996) The Global Burden of Disease. Cambridge, MA: Harvard University Press.

Nakicenovic, N.and R. Swart (eds) (2000) 'Special Report of the Intergovernmental Panel on Climate Change on Emissions Scenarios’, Cambridge University Press, http://www.grida.no/climate/ipcc/emission/index.htm

Newell, P. (2000) Climate for Change: Non-state Actors and the Global Politics of the Greenhouse, New York: Cambridge University Press.

Oldeman, L. (1994) 'The Global Extent of Soil Degradation', in D. Greenland and T. Szaboles (eds) Soil Resistance and Sustainable Land Use, Wallingford, Commonwealth Agricultural Bureau International, http://www.isric.nl/GLASOD.htm

Panayotu, T. (2003) 'Economic Growth and the Environment’, Working Paper, Harvard University.

Pierce, F. (2001) 'Death in a Glass of Water’, The Independent, UK, 19 January http://www.arsenicfilters.com/glass.htm.

Peritore, P. (1999) Third World Environmentalism: Case Studies from the Global South, Gainesville: University Press of Florida.

Perroni, C., J. Whalley and R. Wigle (1999) 'Trade and Environment: Bargaining Outcomes from Linked Negotiations’, CSGR Working Paper No.27/99, University of Warwick.

Prasad, P. (2004) 'Environmental Protection: The Role of Liability System in India', Economic and Political Weekly, 39(3): 257-69.

Smith, K., Corvalan and T. Kiellstrom (1999) 'How much global ill health is attributable to environmental factors?’, Journal of Epidedemiology, 10(5): 573-84. 
Suchak, Y. (2002) Development and Environment Issues with Special Reference to Gandhian Perspective, Gandhian Institution, Bombay Sarvodaya Mandal, http://mkgandhisarvodaya.org/kavita_suchak.htm

UN (1998) UN Human Development Report 1998, New York: Oxford University Press.

UNCCD (1998) The Social and Economic Impact of Desertification in Several Asian Countries: Inventory Study, Geneva: Interim Secretariat of the Convention to Combat Desertification.

UNDP (2000) Human Development Report 2000, Oxford and New York: Oxford University Press.

UNEP (1999) Vital water Graphics: an overview of the state of the World's Fresh and Marine Waters” Nairobi, Kenya.

UNEP (2001) Annual Report, Division of Technology, Industry and Economics. Kobe, Japan

UNEP (2003) Global Environmental Outlook, London and Stirling, VA. USA.

UNESCAP and ADB (2000) State of the Environment in Asia and Pacific 2000, Economic and Social Commission for Asia and the Pacific and Asian Development Bank, New York, United Nations. http://www.unescap.org/enrd/environ/soe.htm

Verbruggen, H., O. Kuik, M. Bennis, H. Hoogeveen and R. Mollerus (1998) 'Environmental Protection Measures: Barriers for South-North Trade?’, Working Paper No. 18, International Institute for Environment and Development, London.

Wallach, L. (1999) Whose Trade Organization: Corporate Globalisation and the Erosion of Democracy, Washington DC: Public Citizen

WCD (2000) Dams and Development: A New Framework for Decision-making, London: Earthscan, http://www.damsreport.org/wcd/_overview.htm

Whalley, J. and B. Zissimos (2000) 'Trade and Environment Linkage and a Possible World Environmental Organization', Environment and Development Economics, 5(4): 510-16.

Whalley, J. and B. Zissimos (2001) 'What Could a World Environmental Organization Do?' Global Environmental Politics, 1(1): 29-34.

Whalley, J. and B. Zissimos (2002) 'Internalisation-based World Environmental Organization’, World Economy, 25(2): 619-42.

WHO (1997) Health and the Environment: Five years after the Earth Summit, Geneva: World Health Organization.

WHO and UNICEF (2000) Global Water Supply and Sanitation Assessment 2000 Report. Geneva and New York. http://www.who.int/water_sanitation_health?Globassessment/Glassessment7pdf

WHO (2002) Environmental hazard kill at least 3 million children aged under 5 every year. http:///www.who.int/inf/en/pr-2002-12.html

Wilkinson, C. (ed.) (2000) Status of Coral Reefs of the World. Townsville: Australian Institute of Marine Science. 
World Bank (2000) Health and Environment. Environment Strategy Paper. World Bank. http://nweb18.worldbank.org/essd/essd.nst/Globalview/healthcareenv.pdf/\$file/healthandenv. pdf

World Bank (2001) 'Montreal protocol: successful partnerships to ozone protection - the case of China, Vol. 1 of 1' World Bank report No. 30423, Washington, DC.

World Commission on Water (1999) World's Rivers in Crisis — Some are dying, others could die. World Water Council http://www.worldwatercouncil.org/visoin/6902B03438178538C125683A004BE974.htm

WRI (World Resources Institute) (1996) World Resources 1996-97, New York: Oxford University Press.

WRI (2000) 'World Resources 2000-2001: People and ecosystems: The fraying web of life', Washington, DC. 